\title{
MODERN ACADEMIC LECTURE: PRO ET CONTRA*
}

\author{
Skrypnykov P.M., Skrypnikova T.P., Bieliaieva O.M., Hmil T.A., Hurzhii O.V., Lysanets Yu.V.
}

Ukrainian Medical Stomatological Academy, Poltava, Ukraine

Стаття присвячена найстарішій організаційній формі навчання - лекції. Наголошуються, що один із основних параметрів, яким повинна відповідати сучасна лекція, - інтерактивність. Автори зазначають, що якісна лекція в медичному університеті (академії), підготовлена кваліфікованим науково-педагогічним працівником, - це надзвичайно ємне педагогічне явище, що має низку переваг, як-от: така лекція є дієвою формою емоційного впливу на свідомість майбутнього лікаря, ефективним засобом деонтологічного виховання, формування професійної самосвідомості й професійної позиції, рефлексії і саморефлексії; вона слугує важливою формою співробітництва й забезпечує безпосереднє творче спілкування лектора з аудиторією; дає змогу залучати здобувачів освіти до новітніх досягнень в галузі охорони здоров'я; слугує дієвим засобом навчання через особистий приклад. Приділяючи увагу вже традиційному (в історичному контексті) питанню щодо недоліків лекції, автори побіжно розглядають бар'єри психолого-педагогічного характеру, пов'язані як із викладачем, так i зі студентами. Показано, що саме ці бар'єри заважають реалізації основних функцій лекції і породжують дискусії щодо лекційної форми навчання. Значну увагу приділено засобам візуалізації лекційного матеріалу. У висновках зазначається, що сучасна академічна лекція повинна відповідати низці передумов, які взаємопов'язані між собою: належна психолого-педагогічна підготовка науково-педагогічного працівника; відповідність його знань сучасному рівню розвитку науки; бездоганне володіння лекційним матеріалом й аудиторією; якісний контингент здобувачів освіти, які мають високий рівень мотивації до навчання та бажання здобувати освіту, оволодівати знаннями, уміннями й навичками; якісна візуалізація лекційного матеріалу.

Ключові слова: медична освіта, академічна лекція, переваги сучасної лекції, контингент здобувачів освіти, інтерактивність, візуалізація.

The article is devoted to lectures as the oldest organizational form of education. It has been emphasized that interactivity is one of the main parameters that a modern lecture must comply with. The authors note that a quality lecture at a medical university (academy), prepared by a qualified research and teaching staff, is an extremely capacious pedagogical phenomenon that has a number of advantages, such as: lecture is an effective form of emotional impact on the future doctor, deontological education, formation of professional self-awareness and professional position, reflection and self-reflection; it serves as an important form of cooperation and provides direct creative communication of the lecturer with the audience; it allows to involve students in the latest advances in health care; it serves as an effective means of learning through personal example. Paying attention to the already traditional (in the historical context) question about the shortcomings of the lecture, the authors briefly consider the barriers of psychological and pedagogical nature, related to both the teacher and the students. It is shown that these barriers hinder the implementation of the main functions of the lecture and generate discussions about the form of lecture. Considerable attention is paid to the means of visualization of lecture material. The conclusions state that the modern academic lecture must meet a number of prerequisites, which are interrelated: proper psychological and pedagogical training of research and teaching staff; correspondence of their knowledge to the modern level of development of science; impeccable mastery of lecture material and audience; high-quality contingent of students who have a high level of motivation to study and the desire to obtain education, acquire knowledge, skills and abilities; high-quality visualization of lecture material.

Keywords: medical education, academic lecture, advantages of modern lecture, contingent of students, interactivity, visualization.

Since antiquity, the history of education has been associated with lecture - the oldest group form of training, which remained the main organizational mode of study until the mid-nineteenth century. Investigating the phenomenon of academic lecture, T. Tyagunova notes that lecture is an "academic dinosaur", which, despite all the historical transformations of the educational system, not only perfectly preserved, but also received a kind of immortality gene [14, p. 40]. Being a highly capacious pedagogical phenomenon, a high-quality academic lecture prepared by a qualified scientific and pedagogical professional has a number of advantages: (1) the specifics of professional training of students, their interests are taken into account in the process of lecturing; (2) the lecture equips a student not only with knowledge, but also with convictions, skills to give a critical assessment of the material under consideration; (3) lecture opens the possibility of direct contact between the lecturer and the listeners, which significantly enhances their attention, while the impression of the material being studied increases significantly not only due to verbal - the so-called "living word", but also paraverbal means (intonation, facial expressions, postures, gestures) used by the lecturer (4) depending on the audience's perception of the lecture material, the lecturer has the opportunity to make the necessary adjustments to its content; (5) lecture teaching is time-saving, because during two academic hours of a highly qualified lecture, a student acquires a much larger amount of scientific information than during self-directed processing of printed (elec-

\footnotetext{
* To cite this English version: Skrypnykov P.M., Skrypnikova T.P., Bieliaieva O.M., hmil T.A., Hurzhii O.V., Lysanets Yu.V. Modern academic lecture: pro et contra // The Medical and ecological problems. - 2020. - Vol 24, № 3-4. - P. 29-32.
} 
tronic) sources; (6) lecture is of special importance for those who plan to associate their future life with professional and pedagogical activity $[1 ; 2 ; 3 ; 4 ; 5 ; 6 ; 7 ; 11$; $12 ; 13 ; 14 ; 15 ; 17]$.

The main functions of academic lecture, according to many modern researchers, are as follows: (1) informational - lecture as a source of scientific information adapted for students, acquaintance with the content, principles and patterns of development of a particular scientific field; (2) indicative - acquaintance with the available literature on the discipline (topics), genesis, current state and prospects of scientific concepts, theories, critical analysis of the state of theory and practice, outlining ways of further scientific research; (3) explanatory clarification of the content of basic concepts, providing definitions for new terms, disclosure of certain patterns; (4) systematizing - building a coherent system of knowledge, integration with other disciplines and organizational forms of learning; (5) evidentiary - argumentation, internal persuasiveness, logic, manipulation of facts, the presence of a sufficient number of convincing examples and justifications, which arouses students' interest in knowledge, love of science, gives impetus to self-directed work, activates their cognitive activity; (6) educational formation of the professional worldview $[3 ; 11 ; 12 ; 13 ; 14$; $15 ; 17]$.

Despite the undeniable educational influences and didactic value of academic lectures, in recent decades there has been a systematic reduction in lecture hours and ardent discussions about this organizational form of learning. It should be noted that one of the first who initiated a wide discussion of lecture was the prominent physician and educator N. Pirogov, who sharply criticized lectures in his "Letters from Heidelberg" [8], in which he suggested to cease perceiving lectures as "the only way to science" and believed that lecture should be only "assistance for students' mental work".

It is worth noting that the results of a survey among students conducted by the Ukrainian researcher A. Kuzminsky showed that the amount of information learned at lectures is about $15 \%$. Such data are often interpreted in favor of the fact that lecture is now a relic, and also serve as one of the arguments used by lecture's opponents. In this context, the data given in V. Kruglikov's article, obtained by questionnaire survey among students of technical and humanitarian universities, also deserve attention: $25.7 \%$ of respondents believe that lectures are not needed in the modern context [5, p. 148].

Despite the fact that the student-centered approach to learning, of course, involves taking into account students' point of view, we should not ignore the fact that even in the 21 st century by no means all students have a high level of motivation to study, in fact, the desire to learn, to be not a passive consumer of knowledge, but an active participant in the educational process. Among other things, N. Pirogov wrote that "students are morally obliged not to be limited to formal-passive attendance at lectures" [8, p. 398]. Therefore, it is worth agreeing with the opinion of the prominent scientist who believed that when students become "actors", lectures become a method of active learning, and gave specific ways to solve this problem. In this regard, he wrote: "Firstly, at the beginning of the course, I would choose a certain guide (textbook, manual - the authors) $<\ldots>$ and would make it a moral obligation, a prerequisite for all students to read it... Secondly, $\mathrm{I}\langle\ldots\rangle$ would choose one of the main sections and define it as the main subject of study at a cer- tain time. Thirdly, I would demand from my readers that each of them bring $\langle\ldots\rangle$ their remarks and questions about the content of this case to the lecture" [8, p. 397]. As we can see, back in 1863, the genius of medicine and pedagogy already promoted the form of interactive lecture, which is becoming increasingly popular in modern university education, medical in particular.

Nevertheless, on the way to a real interactive lecture there are many barriers of psychological and pedagogical nature, associated with both the teacher and students, as evidenced by the statements of $\mathrm{V}$. Kruglikov: among the students, there are more and more people who cannot concentrate on the study of the material for a long time, they cannot remain focused during the self-directed processing of texts, the volume of which is more than one page; modern youth has a poor command of their native language, and a limited vocabulary; a certain number of students do not have the ability to retell texts, convey the content of what is read, and, unfortunately, there is an inability and unwillingness to work independently with texts, to highlight the main idea, to take notes, to summarize what is read; a significant number of students are accustomed to working exclusively on the Internet, such students do not know how to search for reliable scientific information, check its relevance and critically assess the scientific value; some modern students do not know how and do not want to generate texts, write essays, etc., but they are accustomed to the simplest way - to copy these materials from the Internet [5, p. 146]. And this is not a complete list of those negative phenomena that are not commonly made public...

As for teachers, T. Turkot cites the following factors of students' reluctance to work on lectures: "inconsistency of the level of complexity of the material offered at the lecture to the level of preparedness of students for its perception; excessive theorizing of material or, conversely, its simplification up to primitivism; lack of connection between theoretical material and practical significance; lack of students' motivation to study a particular subject due to misunderstanding of its role in the future professional activities; insufficient psychological and pedagogical training of the teacher, the inability to deliver educational material in an interesting and accessible way, to think through each fragment of the lecture, to engage and interest the listeners" [15, p. 195-196].

Meanwhile, the factors cited by both V. Kruglikov [5] and $T$. Turkot [15] do not relate to the lecture, but to what is commonly called the "human factor", i.e., the subjects of the educational process - students and teachers. Therefore, the critique of lecture as an organizational form of the educational process, in our opinion, is primarily related to subjective factors. First of all, it is about the personality of the lecturer, who, according to shrewd expression of N. Pirogov, must not only have the "declamatory skills", but also the desire to convince the listener, excite and engage the audience. We found a similar opinion in studies by S. Arkhangelsky, who was at the origins of higher school pedagogy: "There is a simple formula that determines how to deliver lectures: to attract attention of the audience, to capture attention and keep it throughout the lecture. To do this, in addition to the pedagogical vocation and a sincere desire to be a good lecturer, the teacher needs: excellent knowledge of the subject; masterful combination of content, logic and imagery of the subject; studying the experience of the best lecturers; hard work in preparation for each lecture; the rest will come with time, including diction, gestures, and 
so on" [2, p. 320-321]. Thus, the so-called good lecture, i.e., a lecture delivered by a qualified specialist and an outstanding personality, which should be a teacher in higher medical education, has a number of advantages: direct creative communication of the lecturer with the audience; cooperation; emotional interaction; involvement of students in the latest advances of medical science, which is rapidly developing; learning by personal example.

In this context, we agree with Yu. Ryumina [11], who believes that the use of interactive techniques during the lecture (activation of individual or group work with students, students performing various tasks, assessing the degree of mastered material) not only allows to modernize lectures, move away from the translation of readymade knowledge to students, but also create conditions for dialogue and active interaction. Moreover, such a lecture becomes an act of creative communication between the lecturer and the audience, whose influence on the listener in cognitive and emotional relations is not less than the effect of the material taught during the lecture. The Ukrainian researcher $\mathrm{O}$. Timofeyev is quite right: lecture does not end after its completion, so it is valuable for its prolonged impact, it should remain in the memory of students and urge them to further, in-depth study of the subject [13, p. 72].

As for a lecture at a medical university (academy), it is justly considered an effective form of emotional impact on the mind of the future doctor, a means of deontological influence, a means of forming professional selfawareness and position, reflection and self-reflection. In addition, at the institution of higher medical education there are a number of situations in which lectures are necessary: in medical science, there are new directions, concepts, theories that are not yet covered in textbooks and manuals; already known and researched material needs correction in view of the latest achievements of science and technology; there are different, often contradictory approaches to the interpretation of certain phenomena, theories [13].

Thus, a "good" lecture can take place only under the following conditions: the teacher's skill, proper psychological and pedagogical training, impeccable mastery of material and audience, a quality contingent of students who have a high level of motivation to learn and desire to acquire education. In this context, the results of a survey among physicians are noteworthy, according to which $75 \%$ of respondents consider lectures as a necessary link in professional development, and distinguished such a function of lecture as motivational and stimulating [8]. At the same time, this contingent of students puts forward the following requirements for lecture: scientific character and information capacity in accordance with the current level of functioning of medical science; provability and argumentation; availability of a sufficient number of own clinical examples, facts, substantiations, documents; availability of information on the immediate and long-term results of treatment; clear structure and logic of presentation; methodical processing; accessible and clear presentation of the material by the lecturer; interactivity, activation of listeners' thinking with questions, involvement in discussion

Regarding the methods of conducting lectures in higher medical education, in our opinion, another important aspect deserves attention, such as technical equipment and visual presentation of lecture material. It is well known that a person perceives $15 \%$ of information audi- bly, $25 \%$ - visually (visuality is a multifaceted concept that provides different ways of perceiving information - text, symbols, pictures, videos), and in the case of simultaneous presentation of information by audio and visual ways, its effectiveness perception increases to $65 \%$ [7].

For centuries, the board remained one of the main means of visualization: at first, ordinary wooden, and later - magnetic-marker: on the board, lecturers drew diagrams, wrote formulas, made calculations, proved theorems, refuted hypotheses, anatomists drew the structure of organs, histologists depicted the structure of the cell, chemists and biologists drew formulas. It should be noted that the classic board, despite the latest visual aids, has continued to exist in a modified form as a flipchart, the main advantages of which, as compared to its classic predecessor, are mobility and compactness.

Other common means of visualizing lectures, scientific reports and messages were tables, figures, diagrams, charts on the walls or special structures. A lecturer who delivered a lecture in front of a large audience (sometimes up to 200 people) rarely thought about whether the listeners, who, for example, sat far from the rostrum, see the presented text (information). Unfortunately, for various reasons, for a certain percentage of those present in the lecture audience, this clarity was not available. This is due to the fact that visual acuity is associated with both the features of the visual analyzer and the increase in the background brightness.

Meanwhile, the lecturer needs clarity to comply with the sequence of presentation of the material, its content serves as an additional means of demonstrating the logic of information, a means of structuring it. Other types of visualization are traditionally used at medical universities: demonstration of patients and their case histories, animals with various surgical interventions, phantoms, models, drugs and the like. It always impresses the audience.

For example, differentia specifica of lectures by the famous French neurologist J.-M. Charcot (1825-1893) was to use the latest visual aids at the time, photography in particular. In preparation for lectures, Charcot always used his subtle observations of patients, sketched their movements, photographs of all stages of clinical observation, deformities and contractures [18].

In the 50 s-60s of the last century, stationary portable epidemioscopes, overhead projectors, negatoscopes, slide projectors, etc. appeared and began to be widely introduced into the educational process. Although these tools were certainly more revolutionary than tables or diagrams, they required the purchase of films to demonstrate texts, drawings, and slides, and the process of making them was quite laborious. In parallel with the growth of the level of technical development of society, the means of visualization underwent significant changes. Nowadays, the most widespread form is a multimedia presentation, which means a set of slides, with the help of which the lecturer (author) transmits information to the audience. Certainly, the content and form of the presentation depend on the lecturer, his/her preferences and character. At the same time, one should remember that the development of multimedia presentations requires a scientific approach, because the quality of presentation is assessed by the following parameters: content (compliance of the content with the requests of the target audience, scientific character, specificity, problems, accuracy, reliability of information, conciseness, lack of redundant data); design (font, color scheme, pictures, tables, formulas, symbols, animation); effect (aes- 
thetics, convenience for viewing); structure (structuredness, logical sequence, etc.) [10].

Nowadays, electronic interactive boards are becoming more and more widespread in the educational process, which provide users with almost unlimited opportunities during demonstration of presentations, lectures, trainings, practical classes, seminars. Special attention should be paid to such means of visualization of educational material as educational films, computer videos accompanied by text (sometimes musical accompaniment) and videos that are widely used in medical education at the undergraduate and postgraduate stages. The didactic value of such visualization tools is due to the fact that students, interns and doctors, who improve their skills, have the opportunity to get acquainted, for example, with the latest techniques in surgery, methods of performing procedures, dental in particular.

Despite the method of visualization (table, diagram, multimedia presentation, video), the psychological features of the visual perception by the audience remain typical (see Table 1).

\begin{tabular}{|l|c|c|}
\hline \multicolumn{2}{|c|}{ Attendees } \\
\hline \multicolumn{1}{|c|}{ Visually perceive the text } & Listen to its interpretation by the lecturer & Analyze, memorize, record \\
\hline $\begin{array}{l}\text { Visually perceive graphically condensed } \\
\text { text in the form of diagrams, tables, figures, } \\
\text { photographs }\end{array}$ & Independently interpret & $\begin{array}{c}\text { Analyze on the basis of their own } \\
\text { experience, synthesize information }\end{array}$ \\
\hline
\end{tabular}

In all cases, the mechanism of perception occurs in stages: perception of information, its analysis and synthesis, verbal, creolized processing in the form of a synopsis, which requires a considerable mental effort. This can lead to decreased perception. It should be noted that nowadays it is a common practice, in which, with the consent of the lecturer, students can photograph the main points of the lecture, using this material in the future in the process of self-preparation. Thus, the visualized lecture is a systematized, methodically processed, visually presented information, which serves as a basis for gradual formation of mental concepts and actions, as well as students' awareness of all stages of this processing.

Thus, the modern academic lecture must meet a number of prerequisites that are interrelated: proper psychological and pedagogical training of research and teaching staff; correspondence of their knowledge to the modern level of development of science; impeccable mastery of lecture material and audience; high-quality contingent of students who have a high level of motivation to study and the desire to obtain education, acquire knowledge, skills and abilities; high-quality visualization of lecture material. As for the lecture at a medical university (academy), it remains an effective form of emotional impact on the mind of the future doctor, an effective means of deontological education, involvement in the latest advances in health care, a means of forming professional self-awareness and position, reflection and selfreflection.

\section{References}

1. Алексюк А. Педагогіка вищої освіти України. Історія. Теорія : [підруч. для студ. вищ. навч. закл] / Анатолій Миколайович Алексюк. - К. : Либідь, 1998;560 с.

2. Архангельский С. И. Лекции по теории обучения в высшей школе [Текст] / Сергей Иванович Архангельский. - М. : Высшая школа, 1974;384 с.

3. Бєляєва О.М. Сучасна академічна лекція / О. М. Бєляєва // Світ медицини та біології. 2015;4(53):143146.

4. Бєляєва О. М. Лекторська майстерність викладача вищої школи: історія та сучасність / О. М. Бєляєва // Слово, знак, значення: проблеми, інновації рішення: 2га всеукр. (щорічна) наук.-практ. конф., Львів, 15-17 березня, 2015 р. - Львів : Львівський національний медичний університет імені Данила Галицького. Кафедра фрілософії та економіки, кафедра латинської та іноземних мов, 2015;6-13.

5. Кругликов В. Н. Лекция в эпоху информационного общества и ее перспективы в будущем / В. Н. Кругликов // Научно-технические ведомости СанктПетербургского государственного политехнического университета. Общество. Коммуникация. Образование. 2017;8(1):142 - 151

6. Кузьмінський А. І. Педагогіка вищої школи : [навч. посіб.] / Анатолій Іванович Кузьмінський. - К. : Знання, 2005. - 486 с.

7. Основы педагогики высшей школы / Товажнянский Л. Л., Романовський О. Г., Бондаренко В. В., Пономарев О.С., Черванева 3.О. - Харьков : НТУ “ХПІ”, 2005;600 с.

8. Пирогов Н. И. Избранные педагогические сочинения [Текст]; сост. А. Н. Алексюк, Г. Г. Савенюк / Н. И. Пирогов. - М. : Педагогика, 1985;496 с.

9. Редько І.І. Актуальність удосконалення якості навчання лікарів-інтернів на етапі післядипломної освіти / I.І. Редько, О.М. Чакмазова // Збірн. статей IV Міжнародної наук.-практ.конф. Актуальні питання лінгвістики, профресійної лінгводидактики, психології і педагогіки вищої школи. 2019, Лист 7-8. - Полтава : Вид-во "Астрая", 2019;334-337.

10. Рекомендации по оформлению электронной презентации в СПбГУ ИТМО - Режим доступа: https://edu.itmo.ru/file/pages/211/rekomendacii_po_oforml eniyu_elektronnyh_prezentaciy.pdf

11. Рюмина Ю. Н. Интерактивная лекция как форма обучения в системе профеессиональной подготовки бакалавров / Ю. Н. Рюмина // Вестник Шадринского государственного педагогического института : онлайн версия журн. 2014;1(21): Режим доступа: http://shgpi.edu.ru/nauka/vestnik-shgpi/vestnik2014-1

12. Семеног О. Академічна лекція як професійний комунікативний феномен / Олена Семеног // Естетика і етика педагогічної дії : [зб. наук. праць / головн. ред. Зязюн І.А.]. Київ - Полтава, 2011;2:91-101.

13. Тимофеев А. А. Лекция - высший уровень педагогического мастерства / А. А. Тимофеев // Стоматолог - практик. 2013;4:70-73.

14. Тягунова Т. Академическая лекция (о некоторых чертах университетской практики в ее повседневном осуществлении) / Татьяна Тягунова // Академическая лекция: преподавание и исследование : [сб. науч. ст. / под ред. Тягуновой Т. В., Полонникова А. А.]. - Минск : БГУ, 2010:40-83.

15. Туркот Т. І. Педагогіка вищої школи : [навч. посіб.] / Тетяна Іванівна Туркот. - К. : Кондор, 2011;628 с.

16. Щербина О.М. Роль використання інноваційних технологій у світі майбутніх лікарів / О.М. Щербина, І.С. Бородай, О.І. Скорбач // Збірн. статей IV Міжнародної наук.-практ.конф. Актуальні питання лінгвістики, професійної лінгводидактики, психології і педагогіки вищої школи. 2019, Лист 7-8; Полтава. Полтава: Видво "Астрая"; 2019, с. 448-450.

17. Ягупов В. В. Педагогіка : [навч. пос.] / Василь Васильович Ягупов. К; Либідь, 2002:560 с.

18. Kumar D. R. Jean-Martin Charcot: the father of neurology / Kumar D. R., Aslinia F., Yale S. H. Mazza J. J. // Clinical Medicine \& Research. 2011;9(1):46-49.

Матеріал надійшов до редакції 20.05.2020 